\title{
KETERPADUAN ANTARA BETERNAK PUYUH, LELE DAN AZOLLA DALAM MENGATASI LIMBAH PUYUH DAN MAHALNYA PAKAN LELE
}

\author{
Sudadi \\ Fakultas Pertanian, Universitas Sebelas Maret Surakarta \\ email: sudadi_uns@yahoo.com
}

\begin{abstract}
This IbM program in collaboration with two partners, namely: (1) Breeders quail "Panjer Rino", and (2) Livestock Catfish "Dwipangga". Partner (1) is located in the hamlet of Gunung Sari, Ngringo village, district. Cork, Kab. Karanganyar, with a distance of about $\pm 3.5 \mathrm{~km}$ from Fak. Agriculture UNS. The problem faced by business partners (1) is the production of livestock waste quail (quail droppings) are very high, which is about $200 \mathrm{~kg}$ of waste per day (6 tons per month). Currently, the waste dumped directly into nearby rivers, contaminating the river water. Dirt quail very high in protein (17-21\%). Natural nature catfish food is dirt ("telek"). The problem faced by partners (2) is a high cost to provide quality catfish feed. Catfish feed requirement per week reached 200-250 $\mathrm{kg}$, with an average feed price $\mathrm{Rp} .8 .300$, - per $\mathrm{kg}$. Therefore we need an alternative feed supply, such as pellets of excrement quail that can be produced using animal manure quail. Azolla is the only genus of floating water fern. It can be used as green manure, Azolla is used to feed the fish because they contain high nutritional and floats that can be eaten fish or made pellets. The purpose of this activity is to address the key problems: Partner (1) ie quail livestock waste treatment technology that can be used to manufacture pellets. Partners (2) that address the high cost of feed catfish feed Azolla can use directly and make pellets of Azolla and dirt quail. The method used in this activity is to give guidance to partners and practice on: the use of quail dung to feed catfish; the practice of making pellets using quail dung mixed Azolla, Azolla maintain direct practice in catfish ponds and catfish farming. Outcomes that will result from the planned activities IbM are: pellets of excrement quail and Azolla for catfish feed and Azolla as catfish feed directly.
\end{abstract}

Keywords: quail's waste, catfish, Azolla, catfish feed

\section{PENDAHULUAN}

Program IbM ini bekerjasama dengan dua mitra, yaitu: (1) Peternak puyuh "Panjer Rino", dan (2) Peternakan Lele "Dwipangga". Mitra (1) berlokasi di dukuh Gunung Sari, Desa Ngringo, Kec. Jaten, Kab. Karanganyar, dengan jarak tempuh sekitar $\pm 3,5 \mathrm{~km}$ dari Fak. Pertanian UNS. Permintaan konsumen terhadap teur puyuh dan ikan lele di Karanganyar dan sekitarnya per hari sangat tinggi, belum mampu dipenuhi oleh kedua mitra usaha tersebut.

Peternakan puyuh 'Panjer Rino' merupakan usaha mikro milik Lintang Praharyaning. Lokasi usaha ini berada di dukuh Gunung Sari, Desa Ngringo, Kec. Jaten, Kab. Karanganyar. Manajemen usaha yang dikembangkan berdasarkan manajemen usaha keluarga. 'Panjer Rino' mempekerjakan 2 orang tenaga kerja. Kegiatan usaha yang dikembangkan menempati areal seluas sekitar $300 \mathrm{~m}^{2}$, dengan jenis usaha Peternakan Puyuh.

Peternakan puyuh terdiri dari 1 unit rumah puyuh, dengan populasi burung puyuh 8.000 ekor. Kondisi saat ini, kapasitas produksi telur puyuh yang dihasilkan adalah rata-rata 6.400 telur puyuh per hari, dan harga telur puyuh rata-rata adalah Rp. 220,- per butir. Usaha puyuh ini telah mensejahterakan keluarga, dan memberikan penghasilan ekonomi yang dapat diunduh setiap hari.

Peternakan Lele 'Dwipangga' merupakan usaha mikro milik Aren Dwipa Pangastuti. Lokasi kegiatan usaha ini berada di dukuh Gunung Sari, Desa Ngringo, Kec. Jaten, Kab. Karanganyar. Manajemen usaha yang 
dikembangkan berdasarkan manajemen usaha keluarga. 'Dwipangga' mempekerjakan 2 orang tenaga kerja. Kegiatan usaha yang dikembangkan menempati areal seluas sekitar $400 \mathrm{~m}^{2}$, dengan jenis usaha Peternakan Lele.

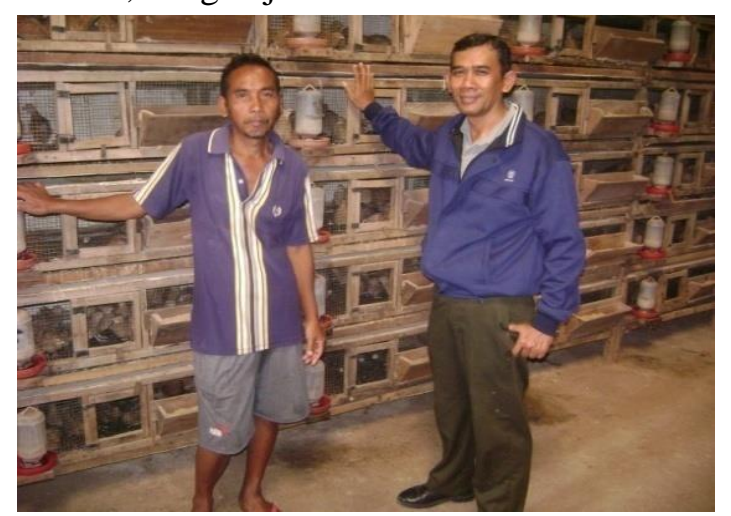

Gambar 1. Peternak puyuh "Panjer Rino"

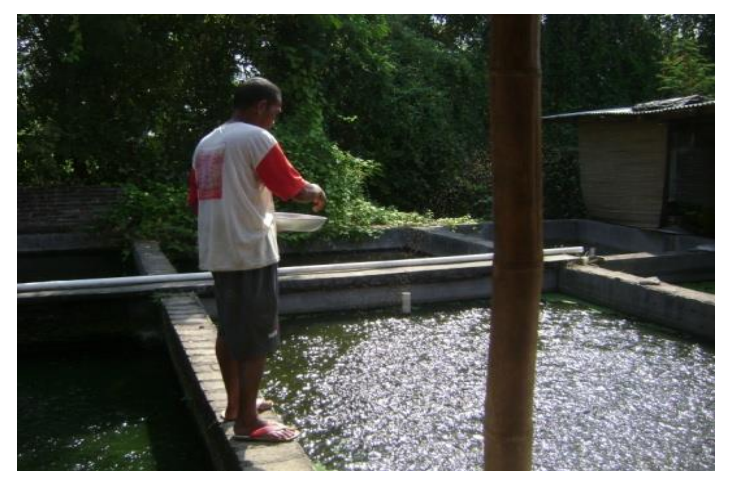

Gamber 2. Peternakan Lele 'Dwipangga'

Budidaya ikan lele dikembangkan pada 18 buah kolam, dan setiap kolam rata-rata berisi $2.000-2.500$ ekor lele. Pada saat ini panen lele baru dapat dilakukan setiap 1 minggu sekali, dengan rata-rata produksi per kolam sekitar 200 - $225 \mathrm{~kg}$, dengan rata-rata harga lele Rp. 12.000,- per kg. Kapasitas produksi lele saat ini juga belum mampu memenuhi permintaan lele yang tinggi untuk melayani konsumen di Karanganyar dan sekitarnya. Disamping itu peluang pemasaran juga terbuka untuk daerah (kota) Yogyakarta. Untuk daerah Yogyakarta membutuhkan sebanyak 12-16 ton ikan lele konsumsi tiap hari. Hal ini dikarenakan banyaknya warung-warung pecel lele yang dibuka di kota pelajar ini setiap malam. (http://www.waspada.co.id)
Di sekitar kolam lele masih terdapat lahan yang kosong dan belum termanfaatkan, sehingga direncanakan untuk lokasi pengembangan pembuatan pakan lele. Pakan lele akan memanfaatkan kotoran puyuh/ limbah peternakan puyuh yang dibuat pelet dengan menggunakan campuran Azolla yang ditanam/ ditaburkan pada kolam yang lelenya masih kecil yang dapat berfungsi sebagai pakan lele yang masih kecil (pertumbuhan Azolla lebih cepat dibandingkan yang dimakan lele). Kelebihan dari yang dimakan lele kecil dapat digunakan sebagai pakan langsung lele yang besar ataupun sebagai campuran pembuatan pelet dari kotoran puyuh. Pembuatan pakan lele tersebut dapat mengurangi polusi lingkungan yang diakibatkan ternak puyuh dan dapat menekan biaya produksi ternak lele yang sangat menguntungkan (Suryono, 2012). Unit usaha pembuatan pakan ini saling menguntungkan kedua belah pihak (Mitra 1 dan Mitra 2).

Permasalahan yang dihadapi oleh mitra usaha (1) adalah produksi limbah ternak puyuh (kotoran puyuh) yang sangat tinggi, yaitu sekitar $200 \mathrm{~kg}$ limbah per hari (6 ton per bulan). Saat ini, limbah dibuang langsung ke badan sungai terdekat, sehingga mencemari air sungai. Kotoran puyuh mengandung protein sangat tinggi (17-21\%). Lele secara kodrat alami makanannya adalah kotoran ("telek") (Suryono, 2012).

Permasalahan yang dihadapi mitra (2) adalah biaya yang tinggi untuk menyediakan pakan ikan lele yang berkualitas. Kebutuhan pakan lele per minggu mencapai $200-250 \mathrm{~kg}$, dengan harga pakan rata-rata Rp. 8.300,- per $\mathrm{kg}$. Oleh karena itu diperlukan penyediaan pakan alternatif, seperti pelet dari kotoran puyuh yang dapat diproduksi dengan menggunakan kotoran ternak puyuh dan Azolla yang dipelihara pada kolam yang lelenya masih kecil. 
Pemanfaatan Azolla yang dibudidayakan di kolam lele yang masih kecil dan pemanfaatan kotoran ternak puyuh untuk bahan pembuatan pelet merupakan wujud nyata dari penerapan keterpaduan antara peternakan puyuh, lele dan azolla. Azolla memiliki kandungan nitrogen yang tinggi dan dapat digunakan sebagai pakan unggas, rumunansia maupun ikan (Khan, 1988). Dengan demikian selain akan memberikan peningkatan penghasilan bagi peternak, maka juga akan meningkatkan kualitas produk lele organik, pengurangan biaya produksi, dan tidak mencemari lingkungan.

\section{METODE}

Metode yang digunakan untuk mengatasi permasalahan utama yang dihadapai mitra (1) adalah teknologi penanganan limbah ternak puyuh untuk pembuatan pelet. Dalam pelet kotoran puyuh dicampur dengan Azolla. Metode yang ditawarkan untuk mengatasi permasalahan yang dihadapi mitra (2) adalah membuat pelet dari kotoran puyuh yang dapat diproduksi dengan menggunakan kotoran ternak puyuh dan Azolla yang dipelihara pada kolam yang lelenya masih kecil.

Partisipasi mitra dalam pelaksanakan program IbM ini adalah : penyediaan bahan baku limbah ternak puyuh, penyediaan tempat budidaya ternak puyuh, lele dan Azolla, penyediaan sumberdaya manusia sebagi subyek untuk dilatih berbagai kegiatan program ini.

\section{HASIL DAN PEMBAHASAN}

Hasil dari kegiatan adalah telah dilaksanakan pembimbingan terhadap mitra, baik mitra 1 (usaha Peternakan Puyuh 'Panjer Rino') maupun mitra 2 (usaha peternakan lele 'Dwipangga). Terhadap mitra 1 dilakukan pembimbingan dalam hal pengelolaan kotoran puyuh untuk dijadikan pelet pakan lele yang akan dicampur dengan azolla, sedangkan terhadap mitra 2 dilakukan pembimbingan dalam hal budidaya azolla sebagai pakan lele secara langsung dan sebagai pelet pakan lele yang dicampur dengan kotoran puyuh.
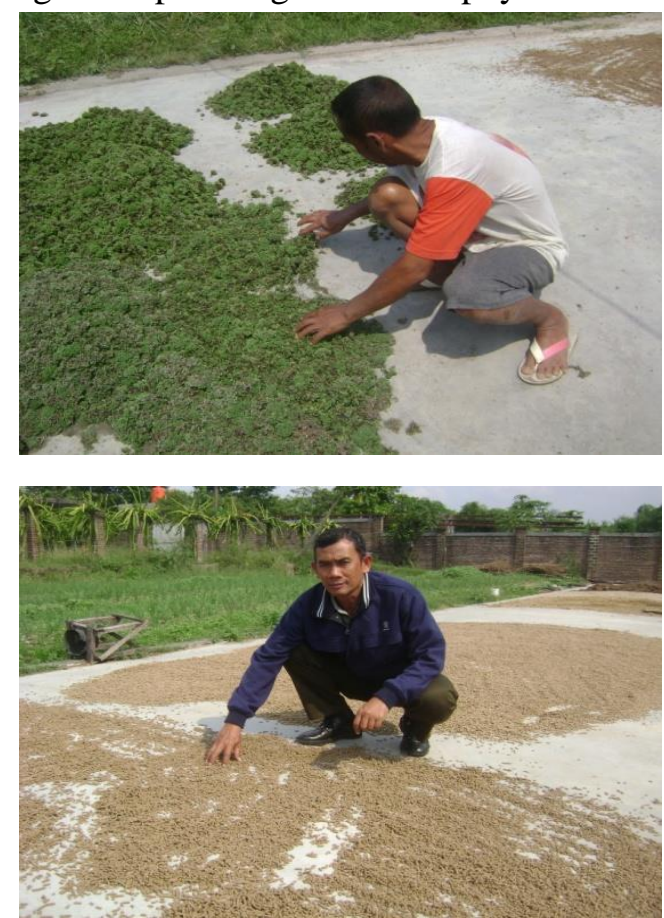

Gambar 3. Azolla dan pelet pakan lele

Disamping itu juga telah dilakukan penyerahan bantuan alat-alat untuk membuat pelet dan alat sederhana untuk penjemuran kotoran puyuh dan pelet.

\section{KESIMPULAN}

Pelaksanaan kegiatan telah berjalan 100 $\%$ dari yang direncanakan, sehingga tindak lanjut dari kegiatan ini adalah evaluasi terhadap pelaksanaan kegiatan dan publikasi kegiatan untuk lebih menyebarluaskan teknologi yang disuluhkan. Selain itu juga melanjutkan pembinaan atau bentuk kerjasama lebih lanjut dengan mitra.

\section{UCAPAN TERIMA KASIH}

Ucapan terima kasih disampaikan kepada Dirjen Pendidikan Dikti, yang telah mendanai kegiatan ini melalui Hibah Ipteks bagi Masyarakat Tahun Anggaran 2015. Ucapan terima kasih juha disampaikan kepada UKM Peternakan Ayam Tumbuh Tepat, dan (2) UKM Pembibitan Tanaman Bejo Agrofarm yang telah bersedia menjadi mitra dan mendukung kegiatan IbM ini. 


\section{DAFTAR PUSTAKA}

Anggraeni, I. 2009. Efisiensi Serapan N dan Hasil Tanaman Padi (Oryza sativa L.) Pada Berbagai Imbangan Pupuk Kandang Puyuh dan Pupuk Anorganik Di Lahan Sawah Palur Sukoharjo (Musim Tanam II). Skripsi S1. Fak. Pertanian UNS. Surakarta.

Anonim. 2009. Tiap hari, 12 ton lele dikonsumsi. http://www.waspada.co.id/ index.php?option $=$ com_content $\&$ view $=$ art icle\&id=35410:tiap-hari-12-ton-leledikonsumsi\&catid=95\&Itemid $=146$

--------. 2011. Kenapa Beternak Puyuh. http://www.forumternak.com/t17-kenapabeternak-puyuh.

-------. 2011. Budidaya Lele di Kolam Terpal. http://bp4kkabsukabumi.net/ index.php/Perikanan/BUDIDAYA-LELEDI-KOLAM-TERPAL.html

Khan, M.M.1988. Azolla Agronomy. UPLB. Los Banos. Phillipine.
Suryono, 2012. Beternak Puyuh Dan Lele Dalam Suatu Keterpaduan. Makalah disampaikan dalam : Pelatihan Kewirausahaan Bagi Calon Purnabakti PNS, Lembaga Penelitian Dan Pengabdian Kepada Masyarakat (LPPM) Universitas Sebelas Maret Selasa, 3 April 2012

Dalam : Kegiatan Pendampingan
Kewirausahaan Untuk Kaum Wanita.
Program CSR PT. Alexis Perdana Mineral
Di Desa Jendi Dan Desa Kaloran
Kecamatan Selogiri, Kabupaten
Wonogiri, Lembaga Penelitian Dan
Pengabdian Kepada Masyarakat (LPPM),
Universitas Sebelas Maret, Sabtu, 5 Mei
2012




\section{Lampiran}

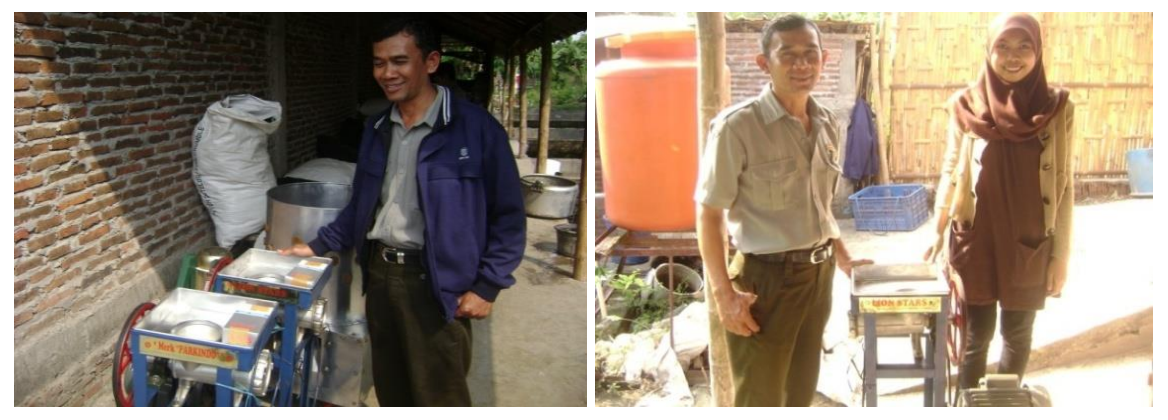

Penyerahan Bantuan Peralatan Pembuat Pelet
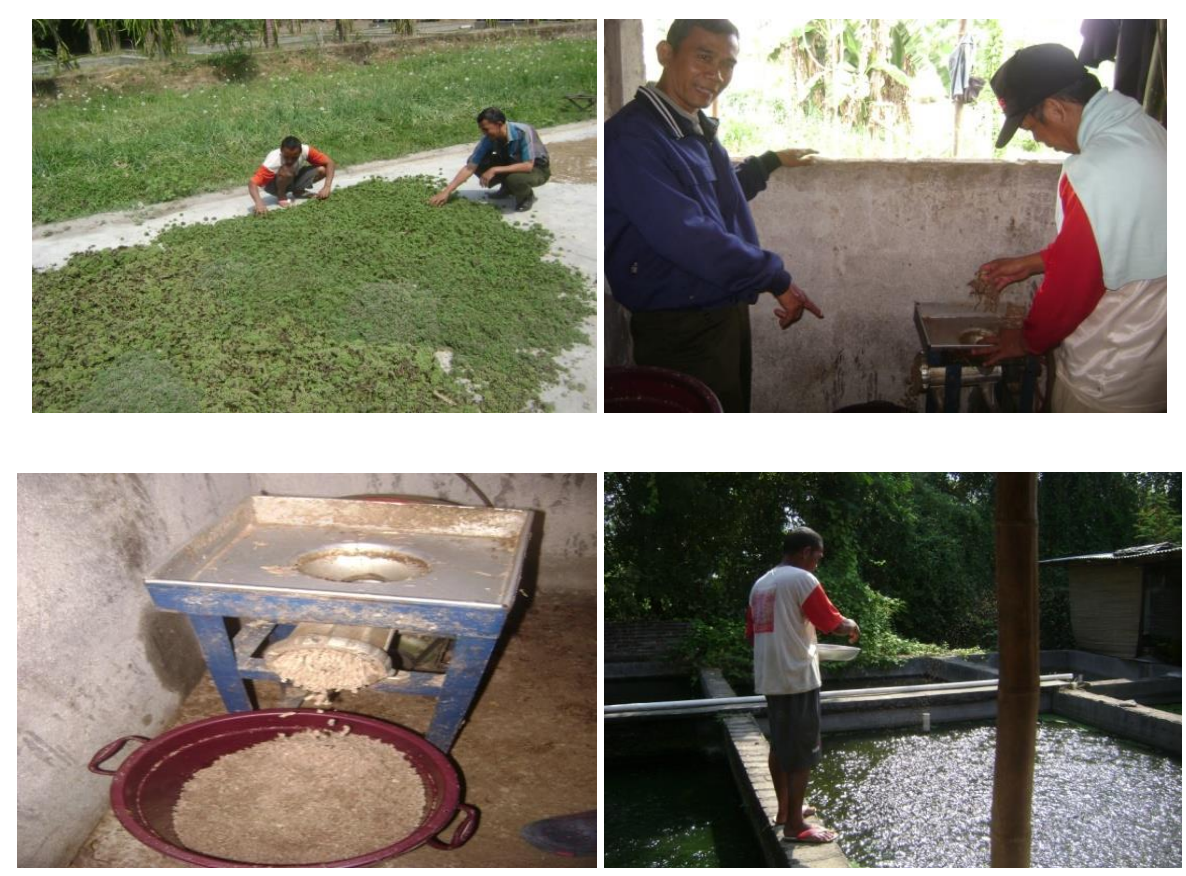

Pelaksanaan Bimbingan Pembuatan Pelet Pakan Lele 